\title{
ESSENTIAL COMPONENTS IN STRUCTURING ASYNCHRONOUS DISCUSSION FORUMS
}

\author{
Dr. Moanes H. TIBI \\ Head of Computer Science Department \\ Faculty of Education, Beit Berl Academic College \\ Kfar Saba, Israel
}

\section{ABSTRACT}

Online learning has been used over the past decade in most disciplines at higher education while the asynchronous online courses are one of the more popular modes of conducting online learning. Within the asynchronous online course, the asynchronous discussion forum plays an important role since it can replace the face to face interaction of the traditional classroom. Since discussions are critical in any learning process, the question is what are the essential components of the asynchronous discussion forum that can make asynchronous discussions more effective for learning and knowledge construction? This paper reviews the literature regarding the main elements and components that makes an asynchronous discussion forum more effective for knowledge acquisition and thereby increases the quality of online learning.

Keywords: Online Learning, asynchronous discussion forums, structured discussion forums, online collaborative learning

\section{INTRODUCTION}

The principles of constructivism emphasize social interaction as a basis for knowledge construction. Most educators agree that interaction and discussion between students and their instructor and among the students themselves are critical in promoting and enhancing online learning (Anderson, 2003; Curtis \& Lawson, 2001; Gokhale, 1995; Harasim, 2002; McAlpine, 2000; Muirhead \& Juwah, 2004; Palloff \& Pratt, 2007; Swan, 2002). According to Walls (2005), the lack of interaction and discussion is an important impediment to the effectiveness of online courses. The most widely used asynchronous tool for the purpose of increasing interaction, group discussion and collaboration among participants in online courses is the discussion forum. Discussion forums are basically used for establishing discussions focused on the content of an online course (Dringus \& Ellis, 2004; Trevino, 2015). They also allow the construction of collaborative knowledge since learners can work together, exchange information and ideas, and comment on each other's work (Markel, 2001; Preece, 2000).

Researchers have reported that while online discussions can facilitate deep learning, that does not happen spontaneously; therefore careful and ongoing instructor mediation and support is required (Al-Shalchi, 2009; Anderson, 2008; Lall \& Lumb, 2010; Lee-Baldwin, 2005; Wu \& Hiltz, 2004). It has been also argued that without proper structure and management of the discussion forum, students may not achieve the expected learning goals (Ali \& Salter, 2004; Andresen, 2009; Biesenbach-Lucas, 2004; Ioannou, Demetriou, \& Mama, 2014; Nandi, Hamilton, \& Harland, 2015; Salter \& Conneely, 2015; Wozniak \& Silveira, 2004).

Consequently, the question is what are the main components of an asynchronous discussion forum, which can make discussions more effective for high levels of learning and knowledge construction? 


\section{MAIN COMPONENTS OF AN EFFECTIVE ASYNCHRONOUS DISCUSSION}

It is clear that the process of Interactions and discussions is a critical component of any learning process, especially when learning is conducted online via CMC tools, such as the learning management system "Moodle" or other environments. Research also shows that simply forming a discussion forum, providing the technology and topics for discussion is not enough to ensure successful and effective online discussion and collaborative learning (Andresen, 2009; Ioannou et al., 2014; Lall \& Lumb, 2010; Nandi et al., 2015; Salter \& Conneely, 2015).

Following sections describe the main elements and components that need to be within a discussion forum in order to make discussions more effective for knowledge construction and collaborative learning (Figure 1). These components are based on the theory of constructivism, on pedagogical principles and on principles of group interaction and collaboration.

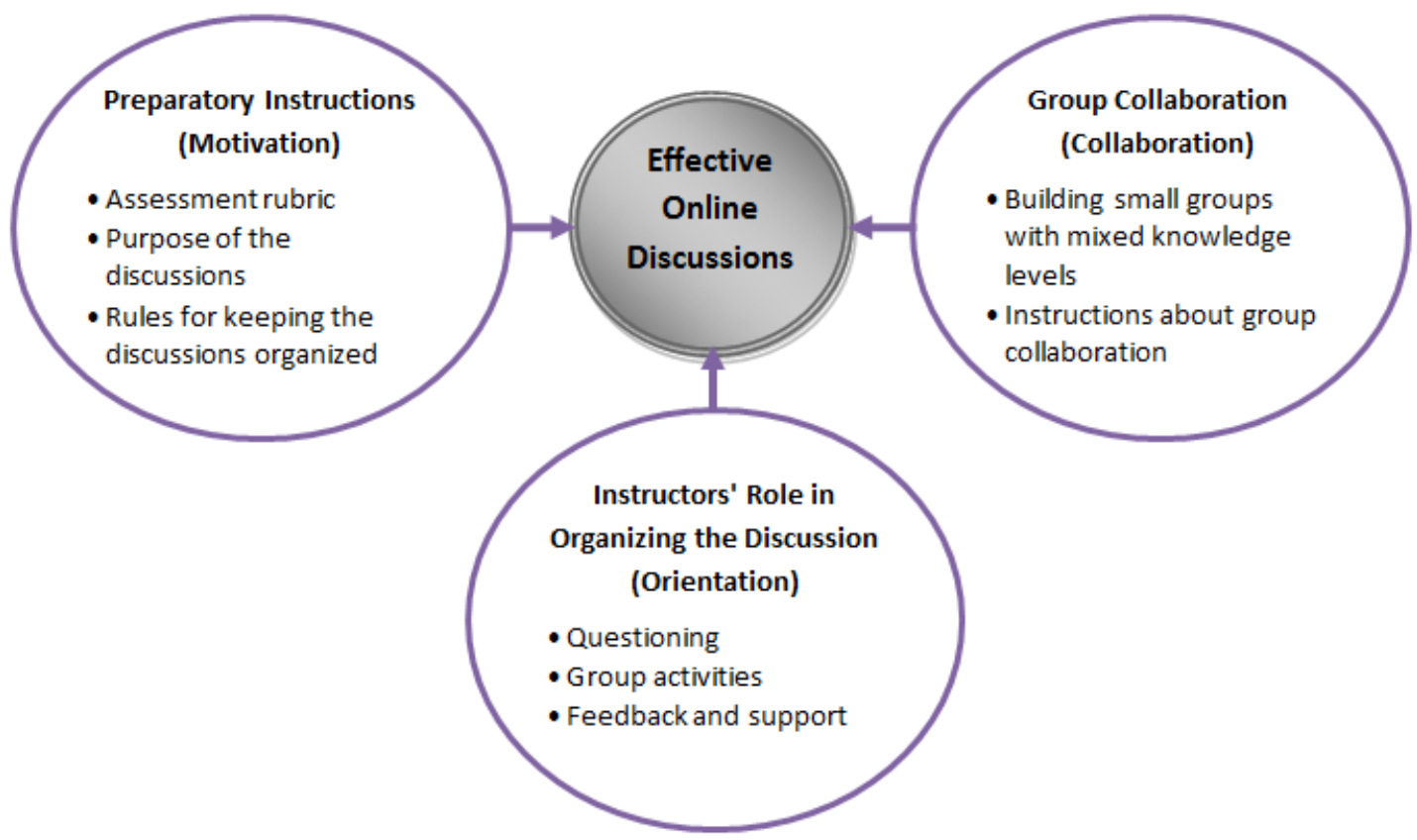

Figure: 1

Main components (MOC) of an effective asynchronous discussion.

\section{Preparatory Instructions about Individual Participation}

Clear and simple directions for online discussion and setting out expectations are important in making student to student interactivity more effective (Mayne \& Wu, 2011; Wozniak \& Silveira, 2004) and in helping and motivating students to contribute to the discussions within the discussion forum (Al-Shalchi, 2009; Ioannou et al. ,2014; Lall \& Lumb, 2010; Roper, 2007). At the beginning of an online course students should receive clear information about how they will be evaluated and other preparatory instructions about the purpose of the discussion forum and how to use it. This information can be described through the following main points:

$>$ Assessment rubric: besides the important information regarding the course content, resources and other information, the course syllabus needs also to show the students how they will be evaluated during the course. Giving students clear information about how they will be assessed during the course will provide them with extrinsic motivation which, in turn, may have a positive effect on their performance and learning outcomes (Dennen, 2000). The assessment rubric can consist of a set of elements such as: (1) grade weight of the participation in the discussion forums, (2) grade weight of the individual and of the group assignments, (3) grade weight of the examination, and (4) grade weight of the 
final group project. In more details, for each assignment in the course students should know about the score and the evaluation criteria of the assignment.

$>$ Purpose of the discussion forum: the purpose of using the discussion forum should be clearly explained to students at the beginning of the course. Roper (2007) claimed that instructors who establish clear expectations about the purpose of the discussion forum and how to use it can expect to encourage richer online dialogue. Also Rose and Smith (2007) argued that instructors must provide the students with clear and simple directions for online discussions that do not cause any confusion among the students. Usually, a discussion forum in an online course is used for enhancing learning through in-depth discussion of the learning topics (Dringus \& Ellis, 2004). Students in online courses need to be encouraged to exchange information and ideas with each other and to post their questions about the learning materials to the discussion forum in order to get answers and support from other students and from the instructor. Students need also to be asked to participate actively and consistently in the discussion forum at whatever time of day was most convenient for them and to relate their discussions to the readings that were set for each week. In addition, students should be informed about the importance of the quality and not the quantity of postings sent to the discussion forum. In principle, students have to know that an educational discussion forum is used only for discussing the learned materials and learning activities of the course and it is not designed for having social discussions. Students may continue to communicate with each other through different CMC tools such as E-mail and other web messaging tools.

$>$ Instructions about using the discussion forum: the preparatory instructions givento the students at the beginning of the online course should also include basic rules about how to use the discussion forum. The purpose of these rules is to preserve the order and organization of the discussions and can be summarized in the following main points:

$\circ \quad$ When writing a response to a given message in the discussion forum, post it as a reply to that message so that participants will find it easy to follow the thread of a topic.

- When introducing a new topic, question or idea to the discussion forum, post it as a new message that makes the subject of your message clear to all.

$\circ$ When quoting, use quotation marks and include the location of the original text.

- Avoid "yes," "no," or repeated responses that clutter the forum and do not add to the discussion. Since this is an educational discussion forum, it is important to maintain the quality of posts rather than the quantity.

\section{Instructions about Group Collaboration}

As noted by Ikpeze (2007), group collaboration allows students to become active learners rather than passive recipients of teaching and it helps to distribute the cognitive load among the members of a group through the exchange of ideas. Students working in small groups tend to learn more of what is taught and retain it longer than when the same content is presented in other instructional design (Davis, 1993; Johnson \& Johnson, 1986, 2004). In order to support online group collaboration the students of the online course can participate in two levels of discussion groups. One level is the small group discussion forum and the other level is the central discussion forum (Figure 2). 


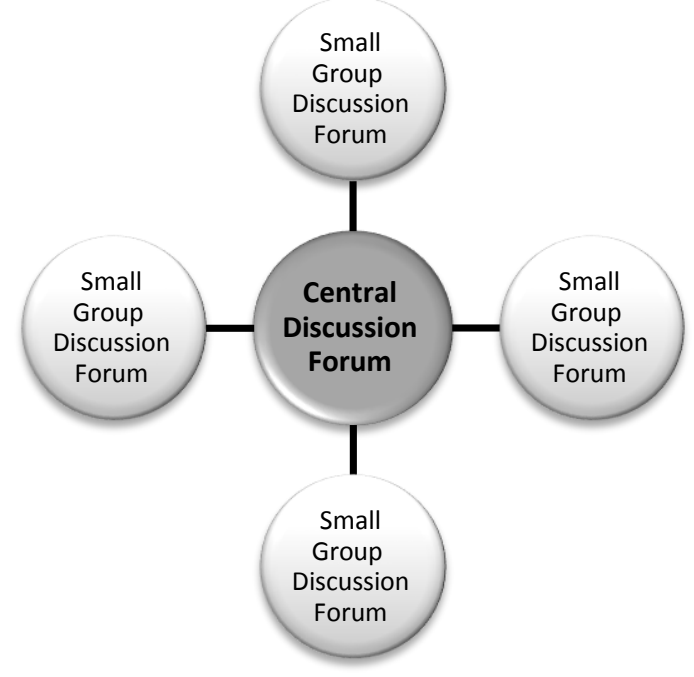

Figure: 2

Levels of the discussion groups.

\section{Small Group Discussion Forum}

For each small group of students, a discussion forum can be specially established in order to support students' interaction and collaboration around the learning subjects and group learning activities. As a part of the instructions, students should be encouraged to discuss the learning subjects and help each other's understanding of the materials of the course as well as to exchange information and collaborate around the group learning activities. The participation in a small group discussion forum is allowed only for the members of that small group and not for other students. The instructor's role in the small group discussion forums is to facilitate students' interaction with the materials and with each other in their knowledge constructing endeavor. This role was described in Benfield (2002) and Mazzolini and Maddison (2007) as a more constructivist "guide on the side" role.

Small groups of students can be constructed according to the following main characteristics:

$>$ Group goal: it should be clearly stated to the members of each small group that they should work together toward the building of a learning group and try to maximize learning for each group member. Thus, students need to be guided to work in their groups for the purpose of sharing and exchanging information and knowledge in order to achieve a deeper understanding of the subjects taught and to complete the required group learning activities.

$>$ Group dynamic: the dynamic of the interaction and collaboration between the students of each small group discussion forum can be determined by the group members themselves. The instructor needs not to be involved in the dynamics of the groups and should not assign roles for the group members. The instructor's role in this case is more to observe and motivate the participation in the small group discussion forums, while giving guidance and support to the students whenever they request it. MacDonell (1992), suggested that the instructor who aims to be conscious of group dynamic should adopt a more "democratic teaching style and be prepared to step aside to give the learner a meaningful role" (p. 169), only intervening when necessary.

$>$ Group structure: group members shape the structure of their group within the general rules and norms that were explained by the instructor at the beginning of the online course. The instructor should not be involved in shaping the patterns of relationships and interactions that can appear within a group.

$>$ Group size: each small group can be composed of three or four students. Davis (1993) claimed that, in general, groups of four or five learners work best. Felder and Brent (1994) argued that "when students work in pairs, one of them tends to 
dominate and there is usually no good mechanism for resolving disputes, and in teams of five or more it becomes difficult to keep everyone involved in the process" (p. 6). Rau and Heyl (1990) mentioned that in larger groups it is difficult to ensure that all members participate. It would seem that small groups made up of three or four students are suitable for collaboration and therefore this group size can be used for constructing the small groups in online courses.

$>$ Group selection: the concept of collaborative learning involves groups of students working together as a team to solve a problem or complete an assignment (Dillenbourg \& Schneider, 1995; Garfield, 1993). Collaborative groups can be formed using different concepts, such as self-selection, random selection, or criterion-based selection (Gokhale, 1995). In selecting collaborative groups, Garfield (1993) noted that the instructor may allow students to self-select groups or groups may be formed by the instructor to be either homogeneous or heterogeneous on particular characteristics. Collaborative groups need to be heterogeneous since students working in small heterogeneous groups learn the subject matter content, appropriate problem-solving and critical thinking skills, as well as skills necessary to work together collaboratively (Roberts, 2004). Felder and Brent (1994) suggested that the "drawbacks of a group with only weak students are obvious, but having only strong students in a group is equally undesirable" (p. 6). They claimed that strong groups have an unfair advantage over other groups and that the members of a strong team tend to divide up the homework and communicate only cursorily with one another, omitting the dynamic interactions that lead to most of the proven benefits of collaborative learning. On the other hand, in groups with mixed knowledge levels or abilities, the weaker students gain from seeing how better students study and approach problems. The stronger students who teach others often find that teaching someone else leads to their own improved understanding of the material allowing them to gain a deeper understanding of the subject (Felder \& Brent, 1994; Garfield, 1993). Therefor small groups of students can be formatted by the instructor to be heterogeneous in the knowledge level. This way of forming the small group assures at least that the best students in the class do not cluster together, leaving the weaker ones to fend for themselves. The knowledge level of the students can be determined according to a pre-test that can be given to all students before starting the online course. It is also possible to determine the knowledge level of the students according to their scores in a course that students were required to take as a prerequisite.

\section{Central Discussion Forum}

As previously mentioned, besides the discussion forums that can be constructed for small groups of students, a central discussion forum should be also established. In the central discussion forum, all students from all groups are requested to participate actively. The discussions in the central discussion forum should be administered by the instructor of the course who needs to play an active, visible part in the forum discussions keeping them on the right track. The increased number of postings to the central discussion forum all over the course can make it difficult for the students to find specific information. Therefore, for each central topic in the course a new central discussion forum can be established in order to contribute to a clear and a better organization to the whole process.

\section{Instructors' Role in Organizing the Discussion}

The instructor can organize the content of the discussion forum through questioning, learning activities and feedback. Following are the descriptions of these components.

$>$ Questioning: discussion questions encourage students to explore the topic and the assigned reading more deeply (Bender, 2003) and are a critical means for achieving learning objectives (Benson, 2007). The instructor should created appropriate discussion questions and activities on different levels and kinds of knowledge (know-what, know-how, and know-why) including higher order questions that ask students to make comparisons, suggest causes and solve given 
problems. Bender (2003) argued that higher order questions provoke constructive thought and open the gates for meaningful discussion. The motivation for this approach is constructivist in nature in that it assumes that student knowledge can be drawn out through student-student and instructor-student interaction involving the asking and answering of questions (Anderson, 2003; Gold, 2001; Markel, 2001; Nandi et al., 2015; Salter \& Conneely, 2015; Trevino, 2015; Weimer, 2013). Additionally, the instructor can post a list of questions and problems to be solved and refer each question to a different student. Students are then required to response to these questions, as well as to make critique and comments on other students' answers, within a given period of time in order to initiate a debate around the learned subjects and thereby promote higher levels of thinking. This questioning activity is more appropriate if the number of students enrolled in the course is not large. Otherwise, the instructor can repeat this kind of activity during the course while taking each time a different group of students with a different set of questions.

Other types of clarification and support, such as offering explanations, clarification of students' understanding and offering suggestions that guide and improve deeper and further discussions, should also be made. This part of the discussion needs to continue over the entire course aiming to encourage more interaction among the participants in order to enhance knowledge acquisition on different levels.

> Group activities: Online collaborative learning aims to provide an environment that supports and enhances online collaboration between students in order to enhance students' learning processes (Kreijns, Kirschner \& Jochems, 2003; Weimer, 2013). Despite the popularity of online collaborative learning, simply putting students together in an online learning group and asking them to work collaboratively does not guarantee that they will engage in meaningful collaborative inquiry (An, Kim \& Kim, 2008; Biesenbach-Lucas, 2004; Johnson \& Johnson, 1986, 2004). Fortunately, there is a growing literature describing how online collaborative learning can be implemented successfully (Achtemeir, Morris \& Finnegan, 2003; Harasim, 2002; Ioannou et al., 2014; Schrum \& Hong, 2002). The key appears to be preparation by the instructor in scheduling collaborative learning activities throughout the experience (Hiltz, 1997) including projects for co-production (Harasim, 2002). Hiltz and Turoff (2002) suggested that collaborative learning activities, which are well-suited for online environments, include debates, group projects, case study discussions, simulations, role-playing exercises, the sharing of solutions for homework problems, and the collaborative composition of essays, stories, and research plans. However, in reality, most online collaborative work is usually relegated to discussion forum conversations, in which students merely generate a dialogue with each other about the weekly readings (An et al., 2008). Although this type of activity can clearly be of relevance, the extent of actual collaboration is usually limited, the reason why well-designed collaborative learning activities need to be combined with online collaborative learning.

Small group discussion forums are basically designed in order to let students work collaboratively on group tasks and projects and thereby increase their knowledge. Each small group can receive well designed collaborative learning activities during the course and use its own discussion forum as a place for work in order to accomplish these activities. Results of each small group can then be posted to the central discussion forum in order to allow for a wide discussion around the activities between all students from all small groups. This opportunity can open the gate for more meaningful discussions and can contribute to a deeper understanding of the learned subjects as well as of the principles underlying the performance of the activities suggested by each group since group members will be requested to defend their proposed solutions in front of the other groups. The whole process of such activities should be observed by the instructor with feedback and support when it is necessary

$>$ Feedback: giving feedback to the students is important since it can help them to reflect upon what they have learned and what they still need to know (Bender, 
2003). Mazzolini and Maddison (2007) recognized that frequent instructor participation is often assumed to encourage students' participation. Kearsley (2000) argued that one factor that strongly affects the amount of student interaction and participation is the level of instructor involvement. However, the instructor needs to maintain a balance between too little and too much participation and should therefore determine the appropriate time to jump in (Mazzolini \& Maddison, 2007). Thus, the instructor should not response to every student post immediately when it is not directed to him in order to give other students the opportunity to response and comment on each other posts. This, in turn, can motivate the students to construct meanings through interaction with each other. However, the instructor should participate regularly in the discussion forum giving feedback, answers, new and follow-up questions and other comments to the students, in order to keep discussions on track and to support the learning process.

In addition to ongoing feedback the instructor can give a positive personal feedback for each student at least once or twice during a semester. In this feedback students can be informed about their level of participation. Students who did not participated enough should be requested to participate more as well as to explain to the instructor about the reasons for their low participation. This personal feedback aims to motivate and help the students to be more active in the discussion forum.

\section{CONCLUSIONS AND RECOMMENDATIONS FOR FUTURE RESEARCH}

Online discussions are an essential part of online courses so the adoption of communication technologies, particularly discussion forums, will continue to grow in online learning environments. It is clear that discussion forums can achieve high levels of learning, but this goal cannot be reached without proper preparations, structuring and management of the discussion and especially intensive instructor interaction with the learners. Using structured discussion forums, which involves problem and project based learning activities, can help in building a community of learners which allows students to become part of a vibrant learning community, rather than an just an independent learner. In fact, the use of structured discussion forums in online courses can be as instructor intensive (instructor to content, instructor to student and assessment of students) as the traditional classroom, if not more. Thus, future work should aim to design and develop better online collaborative learning management systems or platforms that support the sharing and construction of knowledge more easily and effectively. Additionally, these tools should support the instructor in assessing online collaboration and knowledge construction processes. This in turn can reduce the amount of time spent by the instructors on assessment allowing them to invest more time in designing the online course including the teaching and learning activities.

\section{BIODATA and CONTACT ADDRESSES of the AUTHOR}

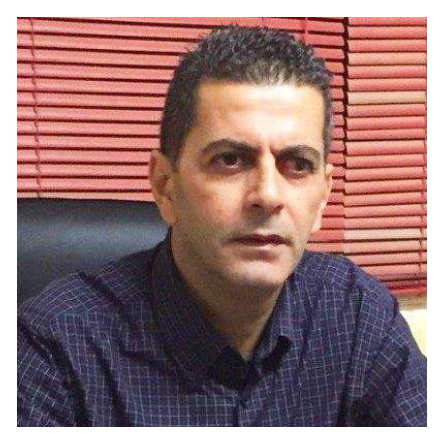

Dr. Moanes H. TIBI holds Bachelor's and Master's degrees in Computer Science from the Rheinische Friedrich-WilhelmsUniversität Bonn in Germany. He earned his Ph.D. from Bar-Ilan University. Dr. Tibi has been lecturing in this field since 1995 and has served as the head of the Computer Science Department at Beit Berl Academic College since 2012. Over the years, he has written various articles and books, participated in national and international Conferences. His principal fields of research and interest include developing teaching and learning models in online environments, and exploring the effect of information technologies on teaching and learning among students and on society in general. Lately, He has been taking an interest in computer science teaching programs for young people. 
Dr. Moanes H. TIBI,

Head of Computer Science Department,

Faculty of Education, Beit Berl Academic College,

Kfar Saba, Israel.

Phone: +97297473109

Email: tibi@beitberl.ac.il

\section{REFERENCES}

Achtemeir, S.D., Morris, L.V. \& Finnegan, C. L. (2003). Considerations for developing evaluations of online courses. Journal of Asynchronous Learning, $\lambda(1)$.

Ali, S., \& Salter, G. (2004). The use of templates to manage on-line discussion forums. Electronic Journal on e-Learning 2(1), 11-18.

Al-Shalchi, 0. (2009). The effectiveness and development of online discussion. (Electronic version). MERLOT Journal of Online Learning and Teaching, 5(1), 104-108.

An, H., Kim, S., \& Kim, B. (2008). Teacher perspectives on online collaborative learning: Factors perceived as facilitating and impeding successful online group work. Contemporary Issues in Technology and Teacher Education, 8(1). Retrieved April 25, 2014 from http://www.citejournal.org/vol8/iss4/general/article1.cfm

Anderson, T. (2003). Getting the mix right again: An updated and theoretical rationale for interaction. The International Review of Research in Open and Distance Learning, 4(2). Retrieved March 02, 2014 from http://www.irrodl.org/index.php/irrodl/article/view/149/230

Anderson, T. (2008). Towards a theory of online learning. (Electronic version). In T. Anderson (Ed.), The theory and practice of online learning (2nd ed., pp.45-74). Edmonton, AB: Athabasca University Press.

Andresen, M. A. (2009). Asynchronous discussion forums: Success factors, outcomes, assessments, and limitations. Educational Technology \& Society, 12(1), 249-258.

Bender, T. (2003). Discussion-based online teaching to enhance student learning: Theory, practice and assessment. Sterling, Virginia: Stylus Publishing.

Benfield, G. (2002). Designing and managing effective online discussions. Learning and Teaching Briefing Papers Series, OCSLD Oxford Brooks University. Retrieved Mai 01, 2014 from

http://www.brookes.ac.uk/services/ocsd/2 learntch/briefing_papers/online disc ussion.pdf

Benson, R. (2007). How to Develop Effective Discussion Questions - Part I: Introduction and Discussion Question Objectives. An Online Learning Magazine for University of Maryland University College Faculty. Retrieved Mai 01, 2014 from http://deoracle.org/online-pedagogy/classroom-communication/effectivediscussion-questions-part-one.html

Biesenbach-Lucas, S. (2004). Asynchronous web discussions in teacher training courses: Promoting collaborative learning-or not? AACE Journal, 12(2), 155-170.

Curtis, D. D., \& Lawson, M. J. (2001). Exploring collaborative online learning. (Electronic version). JALN, 5(1), 21-34.

Davis, B. G. (1993). Collaborative learning: Group work and study teams. In B.G. Davis (Ed.), Tools for Teaching. San Francisco: Jossy-Bass Publishers. Retrieved March 10, 2014 from the University of California at Berkeley web site: http://teaching.berkeley.edu/bgd/collaborative.html

Dennen, V. P. (2000). Task structuring for on-line problem based learning: a case study. Educational Technology \& Society 3(3), 329-336.

Dillenbourg, P., \& Schneider, D. (1995). Collaborative learning and the internet. ICCAI. Retrieved December 17, 2014 from

http://tecfa.unige.ch/tecfa/research/CMC/colla/iccai95 1.html 
Dringus, L. P., \& Ellis, T. J. (2004). Building the SCAFFOLD for evaluating threaded discussion forum activity: Describing and categorizing contributions. 34th ASEE/IEEE Frontiers in Education Conference. Savannah, GA. Retrieved September 10, 2014 from http://fie.engrng.pitt.edu/fie2004/papers/1080.pdf

Felder, R. M., Brent, R. (1994). Cooperative learning in technical courses: Procedures, pitfalls, and payoffs. National Science Foundation Division of Undergraduate Education. Retrieved March 10, 2014 from http://www.eric.ed.gov/PDFS/ED377038.pdf

Garfield, J. (1993). Teaching statistics using small-group cooperative learning. Journal of Statistics Education, 1(1). Retrieved September 26, 2014 from http://www.amstat.org/publications/jse/v1n1/garfield.html.

Gokhale, A. A. (1995). Collaborative learning enhances critical thinking. Journal of Technology Education $7(1)$. Retrieved January 11, 2014 from http://scholar.lib.vt.edu/ejournals/JTE/v7n1/gokhale.jte-v7n1.html

Gold, S. (2001). A constructivist approach to online training for online teachers. Journal of Asynchronous Learning Networks, 5(1), 35-57.

Harasim, L. (2002). What makes online learning communities successful? The role of collaborative learning in social and intellectual development. In C. Vrasidas \& G. V Glass, Distance Education and Distributed Learning (pp. 181-200). Charlotte, NC: Information Age Publishing.

Hiltz, S. R. (1997). Impacts of college-level courses via asynchronous learning networks: Some preliminary results. Journal of Asynchronous Learning Networks, 1(2).

Hiltz, S. R., \& Turoff, M., (2002). What Makes Learning Networks Effective? (Electronic version). CACM, 45(4), 56-59.

Ikpeze, C. (2007). Small group collaboration in peer-led electronic discourse: An analysis of group dynamics and interactions involving preservice and inservice teachers. Journal of Technology and Teacher Education, 15(3), 383-407.

Ioannou, A., Demetriou , S. \& Mama, M. (2014). Exploring Factors Influencing Collaborative Knowledge Construction in Online Discussions: Student Facilitation and Quality of Initial Postings. American Journal of Distance Education, 28(3), 183195.

Johnson, R. T., \& Johnson, D. W. (1986). Action research: Cooperative learning in the science classroom. Science and Children, 24(2), 31-32.

Johnson, D. W., \& Johnson, R. T. (2004). Cooperation and the use of technology. In D. H. Johansson (Ed.). ( $2^{\text {nd }}$ ed.), Handbook of research on educational communications and technology (pp. 785-811). Mahwah, NJ: Lawrence Erlbaum Associates.

Kearsley, G. (2000). Online Education: Learning and teaching in cyberspace. Belmont, CA: Wadsworth Publishing.

Kreijns, K., Kirschner, P. A., \& Jochems, W. (2003). Identifying the pitfalls for social interactions in computer-supported collaborative learning environments: A review of the research. Computers in Human Behaviors, 19, 335-353.

Lall, V., \& Lumb, R. (2010). Successful design, development and delivery of online courses: Lessons from operations management and global leadership. Indian Journal of Economics \& Business, 9(2), 377-384.

Lee-Baldwin, J. (2005). Asynchronous discussion forums: A closer lock at the structure, focus and group dynamics that facilitate reflective thinking. (Electronic version) Contemporary Issues in Technology and Teacher Education, 5(1), 93-115.

MacDonell, W. (1992). The role of the teacher in the cooperative learning classroom. In C. Kessler (Ed.), Cooperative language learning: A teacher resource book. (PP. 163174). Englewood Cliffs, NJ: Prentice Hall.

Mayne, L., \& Wu, Q. (2011). Creating and measuring social presence in online graduate nursing courses. Nursing Education Perspectives, 32(2), 110-114.

Markel, S. L. (2001). Technology and education online discussion forums: It's in the response. Online Journal of Distance Learning Administration, 4(2). Retrieved Mai 15, 2014 from http://www.westga.edu/ distance/ojdla/summer42/markel42.hml

Mazzolini, M., Maddison, S. (2007). When to jump in: The role of the instructor in online discussion forums. Computers \& Education, 49(2), 193-213. 
McAlpine, I. (2000). Collaborative learning online. (Electronic version). Distance Education, 21(1), 66-80.

Muirhead, B., \& Juwah, C. (2004). Interactivity in computer-mediated college and university education: A recent review of the literature. Educational Technology \& Society, $\pi(1), 12-20$.

Nandi, D., Hamilton, M., \& Harland, J. (2015). What Factors Impact Student - Content Interaction in Fully Online Courses. I.J. Modern Education and Computer Science, 7, 28-35.

Palloff, R., \& Pratt, K. (2007). Building online learning communities: Effective strategies for the virtual classroom. Jossey-Bass Wiley. Retrieved from Google books database

Preece, J. (2000). Online communities: Supporting sociability, designing usability. Chichester, UK: Wiley.

Rau, W. \& Heyl, B. S. (1990). Humanizing the college classroom: Collaborative learning and social organization among students. Teaching Sociology, 18(2), 141-155.

Roberts, T. S. (Ed.) (2004). Online collaborative learning: Theory and practice. Hershey, PA: Information Science Publishing.

Roper, A. R. (2007). How students develop online learning skills. Educause Quarterly, 30(1), 62-65.

Rose, R., \& Smith, A. (2007). Online discussions. In C., Cavanaugh \& R., Blomeyer (Eds.), What works in k-12 online learning (pp. 143-160). Washington, D.C.: International Society for Technology in Education.

Rudestam, K. E. \& Schoenholtz-Read, J. (Eds.) (2010). Handbook of Online Learning. London: Sage publications, $2^{\text {nd }}$ edition. Retrieved from Google Books database.

Salter, N., P., \& Conneely, M. R. (2015). Structured and unstructured discussion forums as tools for student engagement. Computers in Human Behavior, 46(1), 18-25.

Schrum, L. \& Hong, S. (2002). Dimensions and strategies for online success: Voices from experienced educators. Journal of Asynchronous Learning Networks, 6(1), 57-67.

Swan, K. (2002). Building learning communities in online courses: the importance of interaction (Electronic version). Education, Communication \& Information, 2(1), 2349.

Walls, C.M. (2005). Some strategies for balancing economies of scale and interaction in online/distance education courses. E-Journal of Instructional Science and Technology (e-JIST) 8(1). Retrieved June 11, 2014 from http://www.eric.ed.gov/PDFS/EJ850357.pdf

Weimer, M. (2013). Structuring Discussions: Online and Face-to-Face. Teaching Professor Blog. Retrieved June 20, 2015 from http://www.facultyfocus.com/articles/teaching-professor-blog/structuringdiscussions-online-and-face-to-face/

Wozniak, H., \& Silveira, S. (2004). Online discussions: Promoting effective student to student interaction. In R. Atkinson, C. McBeath, D. Jonas-Dwyer \& R. Phillips (Eds.), Beyond the Comfort Zone: Proceedings of the 21st ASCILITE Conference, (pp. 956960)

Wu, D. \& Hiltz, S. (2004). Predicting learning from asynchronous online discussions . Journal of Asynchronous Learning Networks, 8(2), 139-152. 